\title{
Changes in Morphological Characters of an Introduced Population of Bilih fish (Mystacoleucus padangensis Bleeker, Pisces: Cyprinidae) in Toba Lake
}

\author{
Nofrita $^{a}$, Dahelmi $^{a^{*}}$, Hafrijal Syandri ${ }^{b}$ and Djong Hon Tjong ${ }^{c}$ \\ ${ }^{a}$ Universitas Andalas, Kampus Unand Limau Manis, Padang 25163, West Sumatera, Indonesia \\ ${ }^{b}$ Universitas Bung Hatta, Ulak Karang, Padang 25133, West Sumatera, Indonesia
}

\author{
ARTICLE INFORMATION \\ Article history: \\ Received: 14 January 2019 \\ Revised: 17 June 2019 \\ Accepted: 25 June 2019 \\ Keywords: \\ Morphology, Bilih fish, Mystacoleucus \\ padangensis, Toba Lake
}

Correspondence:

nofrita2605@gmail.com

\begin{abstract}
A B S T R A C T
Population of Bilih Fish (Mystacoleucus padangensis) in Singkarak Lake has decreased as the effect of intensive exploitation and changes in water use function. Many appropriate works have been conducted for the fish conservation. One of them is introducing Bilih fish population to a new habitat, Toba Lake. After nine years of releasing the fish, there was a hypothesis that these fish had undergone some changes on their morphology compared to their original population in Singkarak Lake. The changes could occur in some morphological characters and also increase or decrease their growth. This study aims to compare the morphology characters between Bilih fish introduced to Toba Lake with the original population in Singkarak Lake. Survey method was used, and 400 samples of fish were taken from each Singkarak and Toba Lakes. Parameters measured were 29 morphological characters. Data were analyzed using Mann Whitney U Test with SPSS 22. The results showed that 27 morphological characters of introduced fish had changed. Characters that had not changed were dorsal fin (anterior end-anal fin distance (DFAF) and preanal distance (PD). Population of Bilih fish in Toba Lake might keep changing in the process of morphological character differentiation as long as environment factors still support the life of Bilih fish.
\end{abstract}

(C) 2019

\section{INTRODUCTION}

Bilih fish (Mystacoleucus padangensis) are endemic fish having economical value and present in Singkarak Lake, West Sumatra. Intensive catching and different management of water use of Singkarak Lake are assumed to be the source of problem for decreasing Bilih fish population. Many efforts have been conducted to conserve the fish population such as releasing the fish produced from hatcheries to the lake and providing artificial reserves (Kartamihardja and Purnomo, 2006).
Other effort that has been taken for speeding up Bilih fish stocks was by introducing them to other location.

Fish introduction is an act of releasing new species of fish into a water in which the same species has not been available in the water (Rahardjo, 2008). The fish can be introduced into waters accidentally or intentionally. In 2003, Bilih fish from Singkarak Lake were introduced into Toba Lake successfully. The purpose of introducing Bilih fish, besides as one of ways for conservation, it is 
also as an effort to increase fish production in Toba Lake (Kartamihardja and Purnomo, 2006).

Monitoring and evaluating the growth, population distribution and cacthing of Bilih fish were conducted in 2005 or two years after releasing fish juvenile. In the new habitat, the growth of Bilih fish can reach length of 10.5$15.0 \mathrm{~cm}$ with weight around 8.0-30.0 gram (Kartamihardja and Purnomo, 2006). Within nine years after releasing, it can be expected that there have been some changes in morphological characters and the growth of Bilih fish in Toba Lake from the original population in Singkarak Lake. The objective of this study was to compare morphological characters and growth of Bilih fish between population introduced in Toba Lake and original population from Singkarak Lake.

\section{RESEARCH METHODS}

Four hundred individual samples of Bilih fish were collected from each Singkarak Lake (100 31' 20.1" E and $\left.00^{\circ} 38^{\prime} 25.2^{\prime \prime} \mathrm{S}\right)$, and Toba Lake (098 56.026' E and $02^{\circ} 39.350^{\prime} \mathrm{N}$ ) (Fig. 1) using gill nets. Each of samples were labelled and fixed in $10 \%$ of formaldehyde and later preserved in $70 \%$ ethanol.

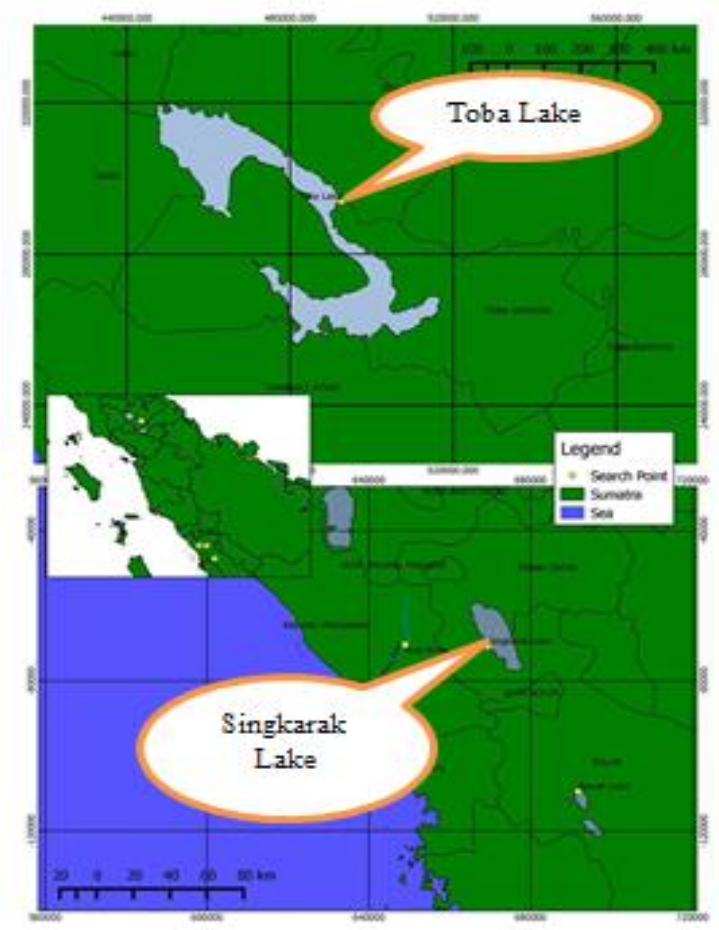

Figure 1. Location of study area in the Singkarak Lake (100 $31^{\prime 20.1}$ "E and 00 $\left.{ }^{\circ} 38^{\prime 2} 25.2^{\prime \prime} \mathrm{S}\right)$ and Toba Lake (098 56.026' E dan $02^{\circ} 39.350^{\prime} \mathrm{N}$ )
Morphometric measurements count were taken point to point from left side of fishes using digital calipers to the nearest $0.01 \mathrm{~mm}$. Of 29 morphological characters have been analyzed according Zahorska (2009), modified from Strauss and Bookstein (1982) (Fig. 2). The measurements taken are as follows: total length (TL), head length (HL), preorbital distance (PrOD), eye diameter (ED), postorbital distance (PoOD), head depth (HD), predorsal distance (PDD), prepelvic distance (PPD), preanal distance (PD), pectoral fin-pelvic fin distance (PFPF), pelvic fin-anal fin distance (PFAF), body depth (BD), dorsal fin (anterior end)-anal fin distance (DFAF), dorsal fin (posterior end)-anal fin (DFPAF), postdorsal distance (PoDD), postanal distance (PAD), caudal peduncle length (dorsal) (CPLD), caudal peduncle length (ventral) (CPLV), caudal peduncle depth (CPD), dorsal fin base length (DFBL), anal fin base length (AFBL), pectoral fin length (PFL), pelvic fin length (PL), caudal upper lobe length (CULL), caudal fork length (CFL), caudal lower lobe length (CLLL), dorsal fin length (DoFL), anal fin length (AFL), and gape (G). Other measurements were 19 environmental parameters including air and water temperatures, water velocity, total suspended solid, total disolved solid, turbidity, conductivity, $\mathrm{pH}$, biological oxygen demand, dissolved oxygen, carbon dioxide free, nitrite, nitrate, ammonia, phosphate, sulfate, alkalinity, hardness, and elevation.

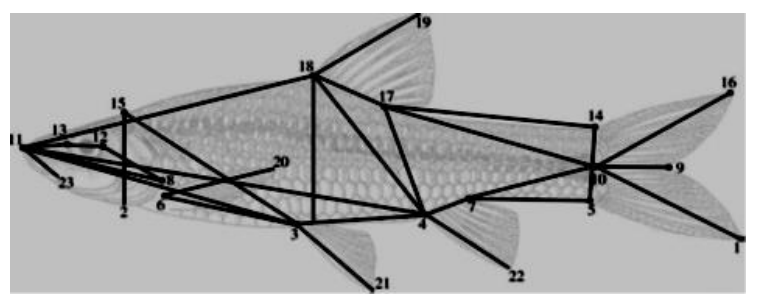

Figure 2. Scheme of of morphometric characters measurement: total length (TL) (11-16); head length (HL) (118 ); preorbital distance (PrOD) (11-13); eye diameter (ED) (13$12)$; postorbital distance (PoOD) (12-8); head depth (HD) (15-

2); predorsal distance (PDD) (11-18); prepelvic distance (PPD) (11-3); preanal distance (PD) (11-4); pectoral fin-pelvic fin distance (PFPF) (6-3); pelvic fin-anal fin distance (PFAF) (3-4); body depth (BD) (18); dorsal fin (anterior end)-anal fin distance (DFAF) (18-4); dorsal fin (posterior end)-anal fin

(DFPAF) (17-4); postdorsal distance (PoDD) (17-10);

postanal distance (PAD) (7-10); caudal peduncle length

(dorsal) (CPLD) (17-14); caudal peduncle length (ventral) (CPLV) (7-5); caudal peduncle depth (CPD) (14-5); dorsal fin base length (DFBL) (18-17); anal fin base length (AFBL) (47); pectoral fin length (PFL) (6-20); pelvic fin length (PL) (3$21)$; caudal upper lobe length (CULL) (10-16); caudal fork length (CFL) (10-9); caudal lower lobe length (CLLL) (10-1); dorsal fin length (DoFL) (18-19); anal fin length (AFL) (422); gape (G) (11-23 (Zahorska et al., 2009). 
In order to standardize the different of overall body size among specimens, all morphometric measurements data were divided by standard length (SL) and presented as ratio. Non-parametric Mann-Whitney $U$ test $(p \leq 0.05)$ was used to compare the morphological and environmental parameters between location. Statistical analyses were done using SPSS version 22.

\section{RESULTS AND DISCUSSION}

Distribution of length and weight of Bilih fish including analysis result of T-test in each location are presented in Table 1. Population of Bilih fish in Singkarak Lake had length around 57.54-112.08 $\mathrm{mm}(82.57 \pm 8.76 \mathrm{~mm})$ with weight around 1.72-14.30 g (5.69 $\pm 2.06 \mathrm{~g})$. In Toba Lake, Bilih fish had length around 62.95-151.78 mm $(104.26 \pm 18.11 \mathrm{~mm})$ with weight that could reach 2.41 $36.47 \mathrm{~g}(12.38 \pm 6.72 \mathrm{~g})$. The size of Bilih fish in Toba Lake was bigger than the one in Singkarak Lake.

The average size of Bilih fish found at Singkarak Lake in this study was smaller than other study done in 1994 by Syandri and Effendie (1997), Syandri (1996), and Azhar (1993). The smaller size of Bilih fish caught in Singkarak Lake was assumed not to be affected by environmental factors but it was caused by exploitation factor. The catching of Bilih fish in Singkarak Lake had been conducted intensively using different equipments with smaller size of nets, $3 / 4$ and $5 / 8$ inch, so that they were not selective in catching fish. the new area maximally. Besides that, in accordance with the purpose of introduction to fulfill the ecological niche, Bilih fish as the result of introduced fish had no enemies to get natural food sources available abundantly. According to Kartamihardja and Sarnita (2010), development of Bilih fish in Toba Lake was supported by the availability of natural food, mainly phytoplankton and detritus. Besides that, the existence of 152 rivers and 212 streams around Toba lake, provided the areas for spawning of the fish. Kartamihardja and Purnomo (2006) reported that the main spawning areas of Bilih fish in Toba lake were in Sipangolu River in Bakara, Sipiso-piso River in Tongging, Sisodang River in Tomok, and Naborsahan River in Ajibata.

However, the length of Bilih fish in Toba Lake has decreased from year to year. A study done by Kartamihardja and Sarnita (2010) in 2008 found that the length of Bilih fish in Toba Lake was around $21.5 \mathrm{~cm}$ and weight was around $9.5 \mathrm{~g}$. The samples taken in June 2009 showed that average length and weight of fish were around $12.3 \mathrm{~cm}$ and $18.1 \mathrm{~g}$. The samples taken in August 2010 found that the average length and weight were around $13.1 \mathrm{~cm}$ and $21.5 \mathrm{~g}$ (Umar and Kartamihardja 2011). Roesma (2011) reported that the length of Bilih fish in Toba Lake was $10.2 \mathrm{~cm}$ in average and the result of this study showed that the length was $10.4 \mathrm{~cm}$. Based on those facts, it can be indicated that Bilih fish in Toba Lake has experienced trouble in their growth. These troubles are assumed because of the increasing exploitation of the Bilih fish in Toba Lake. Using

Table 1. Size distribution of Bilih fish in Singkarak lake and Toba lake

\begin{tabular}{lcccccc}
\hline \multirow{2}{*}{ Location } & \multicolumn{3}{c}{ Length } & \multicolumn{2}{c}{ Weight } \\
\cline { 2 - 7 } & Min & Max & Average & Min & Max & Average \\
& $(\mathrm{mm})$ & $(\mathrm{mm})$ & $\pm \mathrm{SD}$ & $(\mathrm{mm})$ & $(\mathrm{mm})$ & \pm SD \\
\hline Singkarak Lake & 57,54 & 112,08 & $82,57 \pm 8,76^{\mathrm{b}}$ & 1,72 & 14,30 & $5,69 \pm 2,06^{\mathrm{b}}$ \\
Toba Lake & 62,95 & 151,78 & $104,26 \pm 18,11^{\mathrm{a}}$ & 2,41 & 36,47 & $12,38 \pm 6,72^{\mathrm{a}}$ \\
\hline
\end{tabular}

Description: average $\pm \mathrm{SD}$ with supercript is different at level significance $\mathrm{p} \leq 0.05$ based on $\mathrm{t}$-test

The size of Bilih fish in Toba Lake was bigger than the one in Singkarak Lake. Kartamihardja and Purnomo (2006) reported that after 2 years of releasing, Bilih fish in Toba Lake grew well and reached length of 4.0-15.8 $\mathrm{cm}$ with weight of 0.5-30.0 g. As introduced species, Bilih fish certainly had high ability for adapting in a new environment and used natural food sources available in "bagan" and gill nets and also cacthing activity around downstream break the spawning path of Bilih fish that can be the cause for decreasing the growth of the fish in Toba Lake. If those conditions last continuously, it will threaten Bilih fish stocks in Toba Lake as it has been happening in Singkarak Lake. Predation factor by glass fish (Parambassis siamensis) are also suspected to be the 
cause of the decrease in the population of Bilih fish in Toba Lake. Hedianto and Kartamihardja (2015) reported that the glass fish did predation on eggs of Bilih fish. The predation process affects the disruption of recruitment of Bilih fish in Lake Toba so that the population decreases.
The result of measurement showed that all morphological characters of Bilih fish in Toba Lake were longer than the fish in Singkarak Lake (Table 2). Analysis result of Mann-Whitney U Test showed that out of 29 characters of morphology measured, 27 characters $(93 \%)$ showed

Table 2: Mean value \pm SD of the 29 morphology characters population Bilih Fish from Singkarak Lake and Toba Lake and Mann-Whitney U-Test $(n=800)$

\begin{tabular}{|c|c|c|c|}
\hline Characters & Singkarak Lake & Toba Lake & $\begin{array}{c}\text { Mann Whitney U- } \\
\text { Test }\end{array}$ \\
\hline TL & $82.57 \pm 8.76$ & $104.26 \pm 18.11$ & $0.000 *$ \\
\hline PrOD & $4.40 \pm 0.53$ & $5,17 \pm 0.82$ & $0.000 *$ \\
\hline $\mathrm{ED}$ & $4.87 \pm 0.50$ & $5.67 \pm 0.91$ & $0.000 *$ \\
\hline PoOD & $6.86 \pm 0.74$ & $8.49 \pm 1.47$ & $0.000 *$ \\
\hline $\mathrm{HL}$ & $15.48 \pm 1.43$ & $18.60 \pm 2.86$ & $0.000 *$ \\
\hline GA & $4.10 \pm 0.54$ & $4.85 \pm 0.81$ & $0.000 *$ \\
\hline PPD & $33.01 \pm 3.56$ & $41.17 \pm 7.27$ & $0.000 *$ \\
\hline PDD & $31.65 \pm 3.39$ & $39.59 \pm 6.93$ & $0.000 *$ \\
\hline PAD & $45.47 \pm 5.20$ & $57.71 \pm 10.62$ & $0.063^{\mathrm{ns}}$ \\
\hline HD & $12.33 \pm 1.50$ & $14.92 \pm 2.85$ & $0.000 *$ \\
\hline $\mathrm{BD}$ & $18.34 \pm 2.58$ & $23.19 \pm 5.17$ & $0.005^{*}$ \\
\hline DoFL & $14.04 \pm 1.74$ & $18.25 \pm 3.26$ & $0.000 *$ \\
\hline DFBL & $10.12 \pm 1.26$ & $12.34 \pm 2.30$ & $0.000 *$ \\
\hline DFAF & $21.69 \pm 2.66$ & $27.58 \pm 5.77$ & $0.401^{\mathrm{ns}}$ \\
\hline DFPAF & $14.32 \pm 1.86$ & $18.71 \pm 4.01$ & $0.000 *$ \\
\hline CPLD & $21.06 \pm 2.66$ & $27.77 \pm 4.93$ & $0.000^{*}$ \\
\hline CPD & $6.92 \pm 0.73$ & $8.54 \pm 1.53$ & $0.000 *$ \\
\hline CULL & $20.71 \pm 2.30$ & $26.15 \pm 4.99$ & $0.012 *$ \\
\hline CLLL & $20.71 \pm 2.30$ & $26.15 \pm 4.99$ & $0.012 *$ \\
\hline $\mathrm{CFL}$ & $7.67 \pm 1.04$ & $9.29 \pm 1.79$ & $0.000 *$ \\
\hline CPLV & $10.09 \pm 1.44$ & $13.06 \pm 2.47$ & $0.000 *$ \\
\hline AFBL & $8.49 \pm 1.25$ & $10.24 \pm 2.00$ & $0.000 *$ \\
\hline AFL & $9.10 \pm 1.25$ & $11.24 \pm 2.14$ & $0.000 *$ \\
\hline PFAF & $13.76 \pm 2.05$ & $18.09 \pm 3.95$ & $0.000^{*}$ \\
\hline PL & $10.43 \pm 1.32$ & $13.88 \pm 2.26$ & $0.000 *$ \\
\hline PFPF & $17.89 \pm 2.27$ & $23.08 \pm 4.91$ & $0.012 *$ \\
\hline PFL & $11.03 \pm 1.47$ & $14.27 \pm 2.44$ & $0.009 *$ \\
\hline PoDD & $21.82 \pm 2.89$ & $28.82 \pm 5.20$ & $0.000 *$ \\
\hline PoAD & $10.65 \pm 1.47$ & $14.10 \pm 2.55$ & $0.000 *$ \\
\hline
\end{tabular}

Description: TL (total length); (HL) head length; PrOD (preorbital distance); ED (eye diameter); PoOD (postorbital distance); HD (head depth); PDD (predorsal distance); PPD (prepelvic distance); PD (preanal distance); PFPF (pectoral fin-pelvic fin distance); PFAF (pelvic fin-anal fin distance); BD (body depth); DFAF (dorsal fin (anterior end)-anal fin distance); DFPAF (dorsal fin (posterior end)-anal fin); PoDD (postdorsal distance); PAD (postanal distance); CPLD (caudal peduncle length (dorsal)); CPLV (caudal peduncle length (ventral); CPD (caudal peduncle depth); DFBL (dorsal fin base length); AFBL (anal fin base length; PFL (pectoral fin length); PL (pelvic fin length); CULL (caudal upper lobe length); CFL (caudal fork length); CLLL (caudal lower lobe length); DoFL (dorsal fin length); AFL (anal fin length); G (gape). *: significant ( $\leq 0.05)$; ns: non-significant. 
significant difference at $5 \%$ level significance. Those characters were head length (HL), preorbital distance (PrOD), eye diameter (ED), postorbital distance (PoOD), head depth (HD), predorsal distance (PDD), prepelvic distance (PPD), pectoral fin-pelvic fin distance (PFPF), pelvic fin-anal fin distance (PFAF), body depth (BD), dorsal fin (posterior end)-anal fin (DFPAF), postdorsal distance (PoDD), postanal distance (PAD), caudal peduncle length (dorsal) (CPLD), caudal peduncle length (ventral) (CPLV), caudal peduncle depth (CPD), dorsal fin base length (DFBL), anal fin base length (AFBL), pectoral fin length (PFL), pelvic fin length (PL), caudal upper lobe length (CULL), caudal fork length (CFL), caudal lower lobe length (CLLL), dorsal fin length (DoFL), anal fin length (AFL), and gape (G). Characters of dorsal fin (anterior end)-anal fin distance (DFAF) and preanal distance (PD) did not show significant difference (Table 2; Figure 3). Roesma (2011) reported that the difference in morphological characters between population of Bilih fish in Toba and Singkarak Lake was $73 \%$. Some characters - total length, pelvic fin length, dorsal fin length, and mouth length- in the study of Roesma (2011) had not shown differences but in this study they had shown differences. The different range of time made it possible to trigger morphological variation.

So many morphological characters showing differences indicate that one or more factors of environment are inducing morphological character variation in Toba Lake. The history of lake formation, age, width, depth, and elevation are factors that can cause differences in morphological characters. Whitten et al (1987) and Lehmusluoto and Mahbub (1997) stated that Singkarak and Toba Lakes had many differences, for instance, surface width, maximum depth, height, temperature, and ages of the lakes. Those conditions affect fish species living in the lakes. Zahorska et al., (2009) reported that Pseudorasbora parva, fish introduced in Europe, showed big variations in morphology affected by environment condition. The study conducted by Nofrita et al. (2015) showed different morphological characters between Bilih fish in Singkarak and Batang Anai River. Those differences had been induced by water velocity.

Temperature factor was assumed to be the reason for the differences in morphological characters between fish in Singkarak and Toba Lakes. Toba Lake is located higher than Singkarak Lake. The elevation is inversely with temperature. Table 3 shows the data of environment parameters. Water temperature of Singkarak Lake is higher $\left(29.25{ }^{\circ} \mathrm{C}\right)$ than in Toba Lake $\left(25{ }^{\circ} \mathrm{C}\right)$. Temperature directly determines several vital processes of physiology, reproduction and growth of the fish. Temperature affects preliminary phase of fish life, i.e. muscle ontogeny process or shape of fish body (Dimitris et al, 2011) and muscle development (Johnston, 1981, 1993, 2006; Wilkes et al, 2001; Johnston et al, 2009).

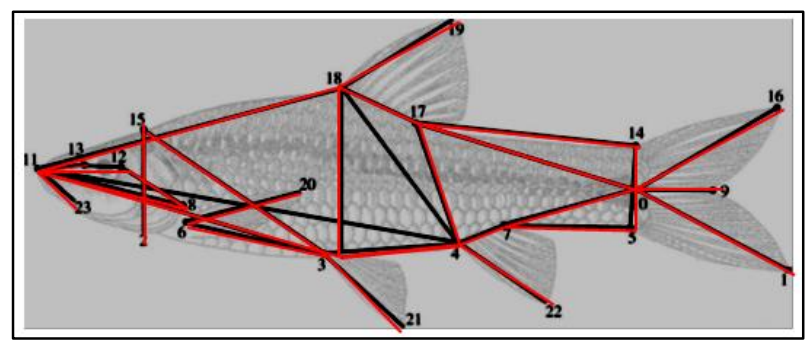

Figure 3. Morphology characters were diffrentiated of Bilih fish from Toba Lake population: head length (HL) (11-8); preorbital distance (PrOD) (11-13); eye diameter (ED) (1312); postorbital distance (PoOD) (12-8); head depth (HD) (15$2)$; predorsal distance (PDD) (11-18); prepelvic distance (PPD) (11-3); pectoral fin-pelvic fin distance (PFPF) (6-3); pelvic fin-anal fin distance (PFAF) (3-4); body depth (BD) (18); dorsal fin (posterior end)-anal fin (DFPAF) (17-4); postdorsal distance (PoDD) (17-10); postanal distance (7-10); caudal peduncle length (dorsal) (CPLD) (17-14); caudal peduncle length (ventral) (CPLV) (7-5); caudal peduncle depth (CPD) (14-5); dorsal fin base length (DFBL) (18-17); anal fin base length (AFBL) (4-7); pectoral fin length (PFL) (6-20); pelvic fin length (PL) (3-21); caudal upper lobe length (CULL) (10-16); caudal fork length (CFL) (10-9); caudal lower lobe length (CLLL) (10-1); dorsal fin length (DoFL) (18-19); anal fin length (AFL) (4-22); gape (G) (11-23);

The avaibility of food can also affect the differences in morphological characters of Bilih fish between Singkarak and Toba Lakes. Morphometric characters of Toba Lake which are wide and deep, provide abundant natural food sources. In accordance with the purpose of introducing Bilih fish is to fill the empty ecological niche, with the absence of fish eating plankton that lives in limnetic zones of Toba Lake, natural food available can be used 
Table 3: Mean value \pm SD of environmental parameters in Singkarak Lake and Toba Lake

\begin{tabular}{lrrr}
\hline Parameters & Singkarak Lake & Toba Lake & $\begin{array}{c}\text { Mann Whitney } \\
\text { U-Test }\end{array}$ \\
\hline Air temperature & $24.750 \pm 0.50$ & $22.750 \pm 0.96$ & $0.025^{*}$ \\
Water temperature & $29.250 \pm 0.50$ & $25.000 \pm 0.82$ & $0.017^{*}$ \\
Water velocity & $0.001 \pm 0.00$ & $0.001 \pm 0.00$ & $1.000^{\text {ns }}$ \\
TSS & $27.053 \pm 8.38$ & $6.468 \pm 0.84$ & $0.021^{*}$ \\
TDS & $96.175 \pm 2.26$ & $81.125 \pm 27.20$ & $0.248^{\text {ns }}$ \\
Turbidity & $1.253 \pm 1.26$ & $1.253 \pm 1.26$ & $1.000^{\text {ns }}$ \\
DO & $6.703 \pm 0.20$ & $5.843 \pm 0.64$ & $0.028^{*}$ \\
BOD & $1.413 \pm 2.02$ & $2.130 \pm 0.86$ & $0.245^{\text {ns }}$ \\
CO2 free & $0.375 \pm 0.39$ & $1.233 \pm 1.07$ & $0.191^{\text {ns }}$ \\
pH & $7.388 \pm 0.29$ & $7.240 \pm 0.36$ & $0.663^{\text {ns }}$ \\
Conductivity & $193.725 \pm 2.16$ & $161.175 \pm 46.77$ & $0.248^{\text {ns }}$ \\
Hardness & $67.000 \pm 8.87$ & $25.625 \pm 10.05$ & $0.021^{*}$ \\
Alkalinity & $8.100 \pm 0.62$ & $8.300 \pm 0.26$ & $0.883^{\text {ns }}$ \\
Nitrite & $0.004 \pm 0.00$ & $0.006 \pm 0.00$ & $0.234^{\text {ns }}$ \\
Nitrate & $1.625 \pm 1.40$ & $1.257 \pm 0.99$ & $0.773^{\text {ns }}$ \\
Ammonia & $0.230 \pm 0.33$ & $0.210 \pm 0.39$ & $1.000^{\text {ns }}$ \\
Phosphate & $0.108 \pm 0.07$ & $0.208 \pm 0.12$ & $0.149^{\text {ns }}$ \\
Sulfate & $11.515 \pm 1.62$ & $8.088 \pm 2.16$ & $0.083^{\text {ns }}$ \\
Elevation & $362 \pm 0.00$ & $905 \pm 0.00$ & $0.019^{*}$ \\
\hline Desiption & & &
\end{tabular}

Description: *: significant $(\mathrm{p} \leq 0.05)$; ns: non significant

optimally by Bilih fish. Furthermore, "pellet" as additional food source for fish reared in floating net system, can also be used by Bilih fish as their food source.

\section{CONCLUSION}

Population of Bilih fish in Toba Lake might keep undergoing the process of character changes as long as the environmental factors continue to support the life of the fish and no other fish as competitors in using natural food sources. As introduced populations, Bilih fish in Toba Lake will adapt in the short periode of time until those populations become adapted to all factors in their new habitat. Populations growing rapidly, at one time will reach a condition where no more changes and maintain the changed characteristics which are suitable with their environment. Until now, there is no knowledge wether the end process of changes will be maintained with specific characters of Toba Lake or back to the characters of Singkarak Lake population looking at the indicated of reducing size of the fish. For those reasons, it needs regular monitoring on the changes of morphological characters of Bilih fish in Toba Lake.

\section{Acknowledgements}

It is our pleasure to thanks Afrizal S, MS for his valuable comments and discussion. Razi, Danil, Feby, Taufiq, Rafdinal, Sukal, Bejo, Hernawati and local people who helped in collecting fish sample from Singkarak Lake and Toba Lake. Author are grateful to Dr. Hidrayani for reading and correction this manuscript.

\section{REFERENCES}

Azhar. (1993). Ecology study of Bilih fish (Mystacoleucus padangensis BLKR.) in Singkarak Lake. West Sumatra.Thesis. Bogor Agricultural Institute. (unpublished).

Dimitris G., Sfakianakis, Leris. I., and Kentouri, M. (2011). Effect of developmental temperature on swimming performance of zebrafish (Danio rerio) juveniles. Environ Biol Fish. 90:421-427.

Hedianto, D. A. and Kartamihardja. E. S., (2015). Biological Characteristics and Impacts of glass fish introduction (Parambassis siamensis, Fowler 1937) in Toba Lake. Proceeding. National Forum 
for Recovery and Conservation of Fish Resources-

V. Hal: 139-152

Johnston, I. A., (2006). Environment and plasticity of myogenesis in teleost fish. J. Exp. Biol. 209: 2249

Johnston, I. A., (1993). Temperature influences muscle differentiation and the relative timing of organogenesis in herring (Clupea harengus) larvae. Marine Biology. 116 (3): 363-379.

Johnston, I. A., (1981). Structure and function of fish muscle. Symp. Zool. Soc. Land. 48:71-113.

Johnston, I. A., Lee, H. T., Macqueen, D. J., Paranthanan, K., Kawashima, C., Anwar, A., Kinghorn, J. R. and Dalmay, T., (2009). Embryonic temperature affect muscle fibre recruitment in adult zebra-fish: Genome-wide changes in gene and microRNA expression assicoated with the transition from hyperplastic to hypertrophic growth phenotypes. J. Exp. Biol. 212:1781

Kartamihardja, E. S. and Purnomo, K., (2006). The successful introduction of Bilih fish (Mystacoleucus padangensis) to its new habitat in Toba Lake, North Sumatra. Proceedings of National Seminar of Fish IV. Jatiluhur.

Kartamihardja, E. S. and Sarnita, A., (2010). Population of Bilih Fish in Toba Lake. Successful introduction of fish, management of implications and future prospects. Research Center for Fisheries Management and Conservation of Fish Resources. Marine and fisheries research and development agency. Issue II. Jakarta.

Lehmusluoto and Mahbub, (1997). National inventory of the major lakes and reservoirs in Indonesia. Expedition Indodanau Technical Report. Helsinki.

Nofrita, Dahelmi, Syandri, H. and Tjong, D. H., (2015). Morphological differentiation between Bilih Fish (Cyprinidae: Mystacoleucus padangensis, Blekeer) in Singkarak Lake and Anai River, West Sumatra, Indonesia. Journal of Entomology and Zoology Studies. 3(5): 171-175

Roesma, D. I., (2011). Diversity and phylogenetic of fishes (Cyprinidae) in lakes and rivers in the area of West Sumatra. Dissertation. Postgraduate of Andalas University. (Unpublished).

Rahardjo, M. F., (2008). Perkembangan IPTEK dalam Pemacuan Sumberdaya Ikan. Dalam Rahardjo et al. (eds). Prosiding Forum Nasional Pemacuan Sumberdaya Ikan I. Pusat Riset Perikanan Tangkap bekerjasama dengan Departemen MSPIPB. Pusat Penelitian Biologi LIPI. Dan Masyarakat Iktiologi Indonesia: 45 - 49.

Strauss, R.E. and Bookstein, F. L., (1982). The Truss: Body Form Reconstruction in Morphometrics. Syt. Zool. 31: 113-135.

Syandri H. and Effendie, M. I., (1997). Age distribution and growth of Bilih fish (Mystacoleucus padangensis, Blkr) in Singkarak Lake. Terubuk. 67(XVIII):2-6.

Syandri, H., (1996). Aspects of reproduction of Bilih fish, Mystacoleucus padangensis Bleeker and it's possibly of hatchering in Singkarak Lake. Dissertation. Bogor Agricultural Institute. (unpublished).

Umar C, and Kartamihardja, E. S., (2011). Long-weight relationship, feeding habit and gonad maturity of Bilih fish (Mystacoleucus padangensis Bleeker) in Toba Lake. North Sumatra. Bawal. 3 (6): 351-356.

Whitten, A. J. S., Damanik, J., Anwar and Hisyam, N., (1987). Ecology of Sumatra. UGM Press.

Wilkes, D., Xie, S. Q., Stickland, N. C., Alami-Durante, H., Kentaouri, M., Sterioti, A., Koumoundouros, G., Fauconneou, B. and Goldspink, G., (2001). Temperature and myogenic factor transcrift levels during early development determines muscle growth potential in rainbow trout (Oncorhynchus mykiis) and sea bass (Dicentrachus labrax). J. Exp. Biol. 204: 2763-2771

Zahorska, E., Kovac, V., Falka, I., Beyer, K., Katina, S., Copp, G. H. and Gozlan, R. E., (2009). Morphological variability of the Asiatic cyprinid, topmouth gudgeon Pseudorasbora parva, in its introduced European range. Journal of Fish Biol. 74: $167-185$ 
